Research Article

\title{
Efficacy and Safety of Cryotherapy in "See and Treat" Program in Jakarta Primary Health Centre
}

\author{
Efektivitas dan Keamanan Krioterapi pada Program See and Treat \\ di Puskesmas Wilayah Jakarta
}

Linda Lestari, Gatot Purwoto, Laila Nuranna

Department of Obstetrics and Gynecology

Faculty of Medicine Universitas Indonesia/

Dr. Cipto Mangunkusumo Hospital

Jakarta

\begin{abstract}
Objective: To evaluate the efficacy and safety of cryotherapy in "See and Treat" program in Jakarta Primary Health Care.

Method: Using descriptive cross-sectional design, data from medical records were taken with total sampling method. We took the VIA result, cryotherapy procedure, first-marriage age, number of marriage, parity, smoking habit, and the use of contraception. Data were analyzed univariately.

Result: Of 86 data, the percentage of cryotherapy to change from positive to negative of VIA result was $90.70 \%$. We did not find the progressivity to invasive cancer.

Conclusion: Cryotherapy is effective to manage the cervical precancerous lesion in "See and Treat" program.

[Indones J Obstet Gynecol 2016; 4-4: 227-233]

Keywords: cryotherapy, Indonesia, see and treat, visual inspection of acetic acid (VIA)
\end{abstract}

\begin{abstract}
Abstrak
Tujuan: Untuk mengevaluasi efektivitas dan keamanan krioterapi pada program "See and Treat" di Puskesmas wilayah Jakarta.

Metode: Dengan desain deskriptif potong lintang, data dari rekam medis diambil dengan metode total sampel. Variabel yang dicatat adalah hasil IVA, tindakan krioterapi, usia pertama menikah, jumlah pernikahan, paritas, kebiasaan merokok, dan penggunaan kontrasepsi. Data dianalisis secara univariat.

Hasil: Dari 86 data yang dianalisis, persentase keberhasilan krioterapi dalam konversi hasil IVA mencapai 90,70\%. Kami tidak mendapatkan progresivisitas menjadi kanker invasif.

Kesimpulan: Krioterapi efektif dan aman dalam mengatasi lesi prakanker serviks pada program "See and Treat".

[Maj Obstet Ginekol Indones 2016; 4-4: 227-233]

Kata kunci: Indonesia, inspeksi visual asetat (IVA), krioterapi, see and treat
\end{abstract}

Correspondence: Linda Lestari,fr.ingdida@gmail.com

\section{INTRODUCTION}

Cervical cancer still becomes the main health problem in the world. World Health Organization (WHO) in 2012 stated that this disease ranked the fourth most prevalent cancer among women. Approximately 528,000 new cases are detected each year, $85 \%$ of which are found in developing countries. From those cases, 266,000 cases die, where 9 of 10 death cases occur in developing countries. ${ }^{1}$ In 2011, Cancer Registry Council of Pathology Specialist Association in Indonesia stated that this disease was the second most prevalent cancer in women with the incidence rate of $3,047(12.27 \%)^{2}$

Cervical cancer has higher rate of incidence in developing countries compared with developed ones. Furthermore, patients suffering from cervical cancer in developing countries are often diagnosed at advanced stage of diseases so that the 5-year survival rate is less than $40 \%{ }^{3}$ Actually, the disease requires 10-20 years to transform from pre-cancer lesions to cancer and whenever it reaches the advanced stage, the survival rate drops significantly. Compared with its first stage, the second, third, and fourth stage have an estimated hazard ratio of $3.09,18.11$, and 53.03; respectively. 4,5

Structured screening program for cervical cancer is responsible for decreasing the incidence and mortality rate of cervical cancer in developed countries. In United States, the incidence of cervical cancer had dropped by $70 \%$ for the last 50 years. ${ }^{6}$ Unfortunately, in the developing countries, the screening is not distributed equally and the 
coverage is still low. Only $5 \%$ of the population has access to the screening program. Apart from that, the health care service is not comprehensive and holistic causing the high prevalence of cervical cancer. This problem also includes of low awareness of the disease among the population. As the population grows, there will be an increase number of cervical cancer patients. ${ }^{7,8}$

World Health Organization analyzed that in the developing countries, screening program using Pap smear cannot significantly decrease the incidence and mortality rate of cervical cancer. Limited budget, low competent resources, and inadequate health care system contribute to the failure of Pap smear screening in those countries. ${ }^{9}$ Visual inspection with acetic acid (VIA) is known as the alternative effective method in detecting precancerous lesion in the developing countries. It is both sensitive (67-92.3\%) and specific (49-99.8\%). ${ }^{10,11}$ Therefore, VIA is considered as one of the most popular screening method for precancer lesion, especially in low-resource health care facility. ${ }^{12}$

The management of precancerous lesion involves cryotherapy, loop electrosurgical excision procedure (LEEP), laser, and knife conization. ${ }^{5}$ However, the limitation of the resource makes screening methods is not feasibly perform. Therefore, to handle this problem, Indonesia has "See and Treat" program, namely screening using VIA and management through cryotherapy. ${ }^{13}$ The effectivity of cryotherapy in treating the precan-cerous lesion ranges from $81.4 \%$ to $96.4 \%$ for cervical intraepithelial lesion (CIN) I and from 68\% to $82.1 \%$ for CIN II-III. ${ }^{14-17}$ The complaint after cryo-therapy procedure is around 5.6\%, including minimal bleeding $(1.3 \%)$. There is no major complication reported after cryotherapy. ${ }^{15,18}$

In Indonesia, the evaluation of IVA after cryotherapy in "See and Treat" program had been done between 2004 and 2006; the effectivity reached $92 \%{ }^{16}$ However, data about the effectiveness of cryotherapy in Indonesia after 2006 was still limited. Therefore, this study aims to describe the VIA result after cryotherapy in "See and Treat" program in Indonesia.

\section{METHODS}

We used descriptive cross-sectional study design using medical records from 2010 to 2015. We recruited by total sampling method. "See and treat" program was a single-visit approach program implemented at the low-resource primary health care in Indonesia. It aimed to diagnose the cervix precancerous lesion through VIA and treat positive VIA result with cryotherapy in Indonesia. The evaluation of VIA conversion was performed 6 months after cryotherapy. Every patient's data was written on the medical record.

\section{Participants}

We included all women who had positive result of VIA, had received the cryotherapy as treatment; then they visited to control in 6 months after cryotherapy and we could track the complete medical records in primary health care. We categorized lost-to-follow-up for subjects who could not be recalled due to inactive number or unavailable contact. Therefore, we excluded those criteria.

\section{Procedure}

History taking and physical examination were performed by the general practitioner in primary health care to exclude the cervicitis, nabothian cyst, and polyp. We detected the cervical precancerous lesion by using a $5 \%$ diluted acetic acid solution. The result of VIA was inspected visually with adequate light source. It was considered positive result if there were acetowhite lesions on the transitional zone close to the squamocolumnar junction. When the VIA result was positive, cryotherapy become the choice of treatment in this program. Cryotherapy using cryoprobe was provided in two cycles, with 3 minutes of freeze and 5 minutes of thaw in each cycle. After the process, we prescribed the analgesic and a dose of antibiotic. We also informed the side effects of cryotherapy and instruction not to have sexual intercourse for a month. The patient was informed to come for follow-up session in a month and six months afterwards. The one-month follow-up after cryotherapy aimed to assess the side effect of cryotherapy, such as severe abdominal cramp, fever more than $38^{\circ} \mathrm{C}$, or bloody and purulent discharge. The six-month follow-up after cryotherapy would like to assess the conversion of VIA. Patients had the conversion of VIA if the VIA result became negative on six-month follow-up. Failure of cryotherapy was divided into failure to achieve VIA conversion and suspected invasive cancer. Further follow-up was done to observe the cause of cryotherapy failure. We took the data from the medical record; thus, we had to contact the subject in every missing data. 


\section{Calculation and data management}

Data were analyzed univariately by separating the conversion of VIA on the six-month follow-up into three groups, namely successful conversion, failure to convert, and suspected invasive cancer. We analyzed the data through Microsoft Excel.

\section{RESULTS}

From 2010 to 2015, there were 143 medical records which showed the positive VIA result. Fiftyseven $(39.86 \%)$ data were excluded because 8 of them $(5.59 \%)$ did not do the cryotherapy and the rest of them (49 data) were lost to follow-up. Four data $(2.80 \%)$ were dropped out due to missing data. Therefore, there were only $86(57.34 \%)$ data continuing to analyze.

\section{Demographic Characteristics}

Of 86 medical records, most of the subjects were $30-39$ years old $(40.7 \%)$ with the first-marriage age of 20-24 years old (52.3\%), having 1 to 3 children, and never smoke (98.84\%). The number of subjects using hormonal and non-hormonal contraceptive were similar (33.72\% vs $29.07 \%)$.

Table 1. Characteristics of Subjects

\begin{tabular}{|c|c|c|c|}
\hline Variables & $\mathbf{n}$ & $\%$ & Median (min-max) \\
\hline Age (years old) & & & $35.0(19.0-57.0)$ \\
\hline$<20$ & 1 & 1.2 & \\
\hline $20-29$ & 18 & 20.9 & \\
\hline $30-39$ & 35 & 40.7 & \\
\hline $40-49$ & 28 & 32.6 & \\
\hline $50-59$ & 4 & 4.7 & \\
\hline First-marriage age (years old) & & & $23.0(16.0-33.0)$ \\
\hline$<20$ & 16 & 18.6 & \\
\hline $20-24$ & 45 & 52.3 & \\
\hline $25-29$ & 19 & 22.1 & \\
\hline $30-34$ & 6 & 7.0 & \\
\hline \multicolumn{4}{|l|}{ History of contraceptive usage } \\
\hline None & 20 & 23.26 & \\
\hline Pill & 15 & 17.44 & \\
\hline Intrauterine device (IUD) & 25 & 29.07 & \\
\hline Injection & 14 & 16.28 & \\
\hline Implant & 2 & 2.32 & \\
\hline Sterile & 0 & 0 & \\
\hline Condom & 0 & 0 & \\
\hline Combination & 10 & 11.63 & \\
\hline \multicolumn{4}{|l|}{ Number of marriage (times) } \\
\hline 1 & 85 & 98.84 & \\
\hline 2 & 1 & 1.16 & \\
\hline \multicolumn{4}{|l|}{ Parity } \\
\hline 0 & 5 & 5.81 & \\
\hline 1 & 27 & 31.40 & \\
\hline 2 & 26 & 30.23 & \\
\hline 3 & 21 & 24.42 & \\
\hline 4 & 6 & 6.98 & \\
\hline 5 & 1 & 1.16 & \\
\hline \multicolumn{4}{|l|}{ Smoking } \\
\hline No & 85 & 98.84 & \\
\hline Yes & 1 & 1.16 & \\
\hline
\end{tabular}




\section{The VIA Result Six Months after Cryotherapy}

"See and Treat" program required the patients to do the repeated VIA test on the six months after cryotherapy to assess the conversion of VIA result. There were $90.70 \%$ cases of VIA positive cases converting to negative; while, the rest of the cases did not show the conversion. None of the cases were progress to become the invasive cancer (Table 2).

Table 2. VIA Result Six Months after Cryotherapy

\begin{tabular}{lcc}
\hline \hline & $\mathbf{n}$ & $\mathbf{\%}$ \\
\hline IVA - & 78 & 90.70 \\
IVA + & 8 & 9.30 \\
Suspicious of invasive cancer & 0 & 0 \\
\hline Total & 86 & 100 \\
\hline \hline
\end{tabular}

\section{DISCUSSION}

"See and Treat" program aims to detect and treat the cervical cancer from its precancerous lesion at the low resource setting of primary health care center. ${ }^{13}$ This is a single visit approach program that using VIA to screen and cryotherapy to treat whether the result is positive. This program can decrease the lifetime risk of cervical cancer from 35 -year-old women who have not been screened on her entire life. ${ }^{16}$

The implementation of "See and Treat" program involves four pillar: Firstly, the training of VIA and cryotherapy; secondly, improving the awareness of the society; thirdly, detection and treatment using VIA and cryotherapy; the last one is referral system activation when obtaining a difficult case that has a high progressivity to cervical cancer. ${ }^{13,16}$ The focus of this study is on the third point which aims to evaluate the VIA conversion after six-month of cryotherapy.

After six-month of cryotherapy, the conversion rate of VIA reached $90.7 \%$. Similar study by Vet JNI, et al. in Jakarta, Tasikmalaya, and Bali from 2007 to 2010 also showed the similar result, namely $92.0 \% .^{19}$ While it seemed that there was a drop on the successful conversion rate of $1.3 \%$, the difference in this proportion did not differ statistically. It was due to the high prevalence of loss to follow-up and/or incomplete data $37.07 \%$ in this study VS $52.60 \%$ in the Vet JNI, et al study). ${ }^{19}$ The target of "See and Treat" conversion rate was still not available. Looking to the number of successful cryotherapy which reached $90.7 \%$; thus, the cryotherapy could be reliable to convert the VIA result.

Subjects that failed having VIA conversion to negative were 30-49-year old (75.0\%) group with the first-marriage age of $20-24$ years old $(87.5 \%)$, history of one marriage (100\%), having 2 children (50\%), and non-smoker. According to the theory, those results were similar to the risk factors of cervical cancer. Aziz MF in 2009 through their study stated that younger first-marriage age (less than 20 years old) had 8 times risk to be cervical cancer. ${ }^{20}$ Pramita S in 2010 concluded that number of parity was also related to the cervical cancer $(\mathrm{OR}=2.59 ; 95 \% \mathrm{CI} 1.02-6.61) .{ }^{21}$ In addition, smoking could also increase the risk of squamous cell carcinoma (RR 1.50; 95\% CI 1.35-1.66). ${ }^{22,23}$ Number of marriage in this study was not suitable to the theory stated that the behaviour of changing partners increased the incidence of cervical cancer up to 4 times. ${ }^{20}$ However, the number of marriages cannot represent the behaviour of changing partner.

Based on the history of contraception, $75 \%$ of the subjects who used injection contraceptive failed to achieve the VIA conversion; while, the other $25 \%$ were using pills as the method of contraceptive. That result was similar to the theory that more than five year consumption of oral contraceptive contributed to 1.9 times risk for cervical cancer. ${ }^{21}$ We did not count the risk of that although contraception is one of the risk factors for the VIA conversion. Although the cryotherapy success rate in "See and Treat" program reached $90.7 \%$, there were 8 people $(9.3 \%)$ who did not show the VIA conversion to negative. Those patients were then referred to Dr. Cipto Mangunkusumo Hospital (RSCM) as the national referral hospital in Indonesia for the further definitive diagnosis and management. The failure of VIA conversion can be caused by several factors, such as equipment, healthcare provider, VIA false-positive, and referral system factor.

Looking to equipment factor, problems that could be happened came from the cessation and leaking of gas flow. ${ }^{24}$ Brief survey from the healthcare providers in this study showed that the cryoprobe could sometimes stop automatically before ending the two cycles of cryotherapy. Unfortunately, no further information was reviewed and analyzed in this study. 
Judging from the healthcare provider factor, problems, such as technical method error, untrained healthcare provider doing the cryotherapy, and lack of update the new methods became the burden for the program's success rate because of failure for the ablation of the cervical precancerous lesion. Observation of the cryotherapy process was performed to evaluate the technique practiced by the primary healthcare provider. Examining from the method, the healthcare providers had used the same method of cryotherapy as what the guideline recommended including 2-cycle cryotherapy with 3 minutes of freezing and 5 minutes of thawing per cycle. The healthcare providers were considered expert in their job as they had done this job for at least 5 years.

In terms of VIA examination, false positive was a common interpretation. The right history taking and interpretation of VIA were necessary to prevent over diagnosis and overtreatment of the cervical precancerous lesion. Observing the process of VIA examination, the supervisor did not confirm the diagnosis. Therefore, the failure of VIA conversion could also be caused by missed diagnosis. In the primary healthcare facilities, the referral of patients to RSCM was a good decision to exclude the possibility of false positive diagnosis.

Another problem was related to the implementation of national healthcare coverage Jaminan Kesehatan Nasional (JKN). In JKN era, the referral system follows the level of health care. Therefore, patients from the primary health care cannot be referred directly to RSCM. This problem was occurred on one patient, whereas, she could not be examined the colposcopy examination due to unavailable tools in the secondary health care. However, the difference of protocol in that hospital contributed to the unsuccessful colposcopy referral.

Ideally, every failure of VIA conversion after cryotherapy should be referred to RSCM to be evaluated in the "See and Treat" program by Female Cancer Program. However, tiered referral system hampered this process. Therefore, recommended advice was either inviting regional doctors to participate in this program or modifying the rules of the referral system to suit this program.

Other problems could also be seen from the side of the primary healthcare. We got 6 loss to followup subjects; thus, it made a confusion for the false positive result. Meanwhile, tracking through phone number or home address was difficult due to the lack of identity data recorded in primary health care.

Taking into consideration of those aspects, the failure of VIA conversion in "See and Treat" program could be caused by lack of cryoprobe quality to ablate the precancerous lesion; lack of referral knowledge to ensure the definitive diagnosis as soon as the conversion failure was known; the complicated referral system held in Indonesia contributing to the delayed colposcopy for definitive diagnosis; no policy for primary health care workers to follow-up post referral patients; lack of knowledge equalization about referral system for colposcopy among regional public hospitals.

While failure of VIA conversion was detected, we did not find the progressing lesion to cervical cancer. Therefore, VIA and cryotherapy technique in "See and Treat" program was considered effective in screening and early treatment for the cervical precancerous lesion cases.

We also evaluated the timing of control after cryotherapy. While this study and Vet JNI, et al considered the first and sixth month after cryotherapy as the suitable control time, WHO recommended that the control should be done a year after cryotherapy. The consideration of the first-month control was to evaluate the side effects of cryotherapy; while, the consideration of the sixthmonth control was to evaluate the VIA conversion. The cut-off of 6 months was considered as the novelty of this program in Indonesia. Prompt evaluation of the cases was expected to be able to minimize the incidence of cervical cancer progressivity. Two studies having been conducted in Indonesia proved the constancy of VIA conversion in this program.

The number of loss to follow-up in Indonesia was still high. Therefore, the system of patients' identity registry, such as patients' telephone number and the system of reminding patients, such as by contacting the patients at the time of control should be considered.

In terms of side effects, the side effect due to cryotherapy was only happened on one subject. We could state that cryotherapy was safe enough. This result was supported by Blumenthal, et al., Vet JNI, et al., and Fong J, et al. as their studies showed the similar result. $16,18,25$ However, they did not 
mention the proportion of side effect occurrence in post cryotherapy patients. Sankaranarayanan R, et al. observed that the side effects and complications of cryotherapy were happened only in a small proportion of the population and they were not life-threatening. ${ }^{14}$ Therefore, cryotherapy was a safe treatment method for precancerous lesion. However, there were still no studies that focused on side effects of cryotherapy. Therefore, further studies should be held to evaluate the degree of safety from cryotherapy.

\section{CONCLUSION}

More than $90 \%$ (90.7\%) women showing VIApositive have VIA conversion after 6 months of cryotherapy. We do not find the progression to invasive cancer in 6 months. Therefore, cryotherapy in this program is effective in the early management cervical precancerous lesion.

\section{RECOMMENDATION}

Some recommendations for the next study consist of the need to evaluate "See and Treat" program from other aspects to further increasing the coverage rate; the need of further assessment about the aetiology of VIA-conversion failure, such as the false-positive of VIA result, the quality of cryoprobe, the competency of user, and the impact of referral system nowadays in contributing to the barrier of making definitive diagnosis; the regional doctors should be included in implementing this program in regional general hospital or the rules of tiered referral system of JKN should be modified to suit this program; the recommendation of a-year control after cryotherapy as mentioned by WHO can be implemented in Indonesia; the need of patients' information registry to remind patients to control the VIA conversion.

\section{REFERENCES}

1. World Health Organization. Cervical cancer: estimated incidence, mortality, and prevalence worldwide in 2012 [serial on the internet]. GLOBOCAN 2012 (IARC), Section of Cancer Surveillance. 2016 Jan 07 [cited 2016 Jan 07]. Available from: http://globocan.iarc.fr/old/FactSheets/cancers/cervix-new.asp

2. Direktorat Jenderal Pelayanan Medik Departemen Kesehatan RI, Badan Registrasi Kanker Perhimpunan Dokter Spesialis Patologi Indonesia, Yayasan Kanker Indonesia. Kanker di Indonesia tahun 2011: data histopatologik. Jakarta; 2015.
3. Dhaubhadel P, Vaidya A, Choudhary P. Early detection of precursors of cervical cancer with cervical cytology and visual inspection of cervix with acetic Acid. JNMA. 2008; 47(170): 71-6.

4. Seamon LG, Tarrant RL, Fleming ST, Vanderpool RC, Pachtman S, Podzielinski I, et al. Cervical cancer survival for patients referred to a tertiary care center in Kentucky. Gynecol Oncol. 2011; 123(3): 565-70.

5. Andrijono. Kanker serviks. Ed. 3. Jakarta: Balai Penerbit Fakultas Kedokteran Universitas Indonesia; 2010.

6. Saslow D, Runowicz CD, Solomon D, Moscicki AB, Smith RA, Eyre HJ, et al. American Cancer Society guideline for the early detection of cervical neoplasia and cancer. CA. 2002; 52(6): 342-62.

7. World Health Organization. Comprehensive cervical cancer control. A guide to essential practice. Geneva : WHO, 2006.

8. Depkes RI. Skrining kanker leher rahim dengan metode inspeksi visual dengan asam asetat (IVA). Jakarta: Depkes, 2008.

9. Bharani B, Phatak S. Acetic acid visualization of the cervix an alternative to colposcopy in evaluation of cervix at risk. J Obstet Gynecol Ind. 2005; 55: 530.

10. Ocviyanti D. Tes Pap, tes HPV dan servikografi sebagai pemeriksaan triase untuk tes IVA positif: upaya tindak lanjut deteksi dini kanker serviks pada fasilitas kesehatan dengan sumber daya terbatas beserta analisis sederhana efektivitas biayanya. Maj Obstet Ginekol Indones. 2007; 31(4): 201-11.

11. Sankaranarayanan R, Gaffikin L, Jacob M, Sellors J, Robles S. A critical assessment of screening methods for cervical neoplasia. Int J Gynaecol Obstet. 2005; 89 Suppl 2: S4-S12.

12. Nuranna L. Penanggulangan kanker serviks yang sahih dan andal dengan model proaktif-VO (proaktif, koordinatif dengan skrining IVA dan terapi krio) [Disertasi]. Jakarta: Universitas Indonesia; 2005.

13. Budiningsih S, Nasution K. Report on the female cancer program see and treat Indonesia 2011: executive summary. Female Cancer Program. 2011.

14. Lewis KDC, Sellors JW, Dawa A, Tsu VD, Kidula NA. Report on cryotherapy service for women with cervical intraepithelial neoplasia in a district hospital in Western Kenya. Afr Health Scienc. 2011; 11(3): 370-6.

15. Dhaubadel P, Vaidya A, Chouudhary P. Early detection of precursors of cervical cancer with cervical cytology and visual inspection of cervix with acetic acid. J Nepal Med Assoc. 2008; 47(107): 71-4.

16. Nene BM, Hiremath PS, Kane S, Fayette JM, Shastri SS, Sankaranarayanan R. Effectiveness, safety, and acceptability of cryotherapy by midwives for cervical intraepithelial neoplasia in Maharashtra, India. Int J Gynecol Obstet. 2008; 103(3): 232-6.

17. Sankaranarayanan R, Rajkumar R, Esmy PO, Fayette JM, Shanthakumary S, Frappart L, et al. Effectiveness, safety and acceptability of 'see and treat' with cryotherapy by nurses in a cervical screening study in India. Bri J Cancer. 2007; 96(5): 738-43.

18. Blumenthal PD, Gaffikin L, Deganus S, et al. Cervical cancer prevention: safety, acceptability, and feasibility of a singlevisit approach in Accra, Ghana. Am J Obstet Gynecol. 2007; 196: 407.e1-407.e4. 
19. Vet JNI, Kooijman JL, Henderson FC, Aziz FM, Purwoto G, Susanto H, et al. Single-visit approach of cervical cancer screening: see and treat in Indonesia. Bri J Cancer. 2012; 107: 772-7.

20. Aziz MF. Gynecological cancer in Indonesia. J Gynecol Oncol. 2009; 20(1): 8-10.

21. Paramita S, Soewarto S, Widodo MA, Sumitro SB. High parity and hormonal contraception use as risk factors for cervical cancer in East Kalimantan. Med J Indones. 2010; 19: 268-72.

22. Clifford GM, Polesel J, Rickenbach M, Dal Maso L, Keiser O, Kofler A, et al. Cancer risk in the Swiss HIV Cohort Study: associations with immunodeficiency, smoking, and highly active antiretroviral therapy. J Nat Cancer Inst. 2005; 97(6): 425-32.
23. Appleby P, Beral V, Berrington de Gonzalez A, Colin D, Franceschi S, Goodhill A, et al. Cervical cancer and hormonal contraceptives: collaborative reanalysis of individual data for 16,573 women with cervical cancer and 35,509 women without cervical cancer from 24 epidemiological studies. Lancet. 2007; 370(9599): 1609-21.

24. World Health Organization. Cryotherapy for treatment of cervical pre-cancers [slide presentation]. 2015 [cited 2015 Dec 14].

25. Fong J, Gyaneshwar R, Lin S, Morrrell S, Taylor R, Brassil A, et al. Cervical screening using visual inspection with acetic acid (VIA) and treatment with cryotherapy in Fiji. Asian Pacific J Cancer Prev. 2014; 14: 20757-62. 